\title{
Laparoscopic versus Open Cholecystectomy in Cirrhotic Patients: A Prospective Comparative Study
}

\author{
BOSAT E. BOSAT, M.D.*; NABIL A. ALANSARY, M.Sc.** and MOSTAFA A. AHMED, M.D.* \\ The Department of General Surgery, Faculty of Medicine for Girls, Al-Azhar* and Ain Shams** Universities, Cairo, Egypt
}

\begin{abstract}
Background: Prevalence of gallstones in cirrhotics is estimated at $29-46 \%$ and thus is three times as high as those without liver cirrhosis. Cirrhosis increase incidence of gallstones formation (black stones) with an overall prevalence of $25 \%$ to $30 \%$

Aim Study: To compare between the rationale, risk and morbidity of open cholecystetomy versus and laparoscopic cholecystectomy in cirrhotic patients. As regard to operative time, intra operative and post-operative blood loss, time to resume diet, complications, mortality incidence, and postoperative subjective pain score.
\end{abstract}

Patients and Method: This study was a prospective comparative study on laparoscopic versus open cholecystectomy in cirrhotic patients. The cases were performed in the period from April 2016 till October 2018. 100 patients with symptomatic gallstone disease and liver cirrhosis including Child class A or Child class B, were randomly divided into two groups, Group (A): Laparoscopic Cholecystectomy (LC) and Group (B): Open Cholecystectomy (OC).

Results: In LC group two cases (4\%) were converted to open cholecystectomy. Mean surgical times were significantly shorter in LC (Group A) group. The mean +SD (in minutes) of OC (Group B) and LC (Group A) was $97.69 \pm 15.79$ versus $63.58 \pm 9.93$, respectively, $(p<0.001)$, associated with significantly higher intraoperative bleeding in OC group $(p<0.001)$. The mean time to resume diet (hours) was 10.69 \pm 5.41 in (Group A) it was significantly earlier than in (Group B) $24.15 \pm 6.74(p<0.001)$. The length of hospital stay (days) was significantly longer in (Group B) with a mean hospital stay 5.08 \pm 1.56 , compared with a mean hospital stay $2.60 \pm 0.61$ for (Group A) $(p<0.001)$ with low post-operative morbidity and no operative mortality.

Conclusion: Laparoscopic Cholecystectomy (LC) offers safe and effective surgical treatment for cirrhotic patients of (Child class A and early B) suffering from gallstone disease, as it has lower morbidity, shorter operative time; early resumption diet with less need for blood transfusion and reducing hospital stay than OC.

Correspondence to: Dr. Nabil A. Alansary, E-Mail: dr.nabilansary@gmail.com
Key Words: Cirrhosis - Laparoscopic cholecystectomy (LC) - Open cholecystectomy (OC).

\section{Introduction}

PREVALENCE of gallstones in cirrhotics is estimated at $29-46 \%$ and thus is three times as high as those without liver cirrhosis. Cirrhosis increase the incidence of gallstones formation (black stones) with an overall prevalence of $25 \%$ to $30 \%$ [1] Some complications of Cirrhosis are considered as risk factors for gall stones formation such as decreased bile salt synthesis and malabsorption, chronic hemolysis, and a hyperestrogenic state, all of which increase gallstone formation [2] . Cirrhosis represents the end of all chronic liver diseases. In its decompensated form, cirrhosis can result in portal hypertension and hepatic dysfunction [3]

Open Cholecystectomy [OC] and Laparoscopic Cholecystectomy (LC) are two common procedures to treat gallbladder diseases performed by hepatobiliary surgeons [4]. The severity of cirrhosis, assessed with Child-Pugh classification, is a major determinant in deciding which treatment approach is optimal [5].

The present study is a prospective randomized study comparing the result of OC and LC in patients with compensated cirrhotic and symptomatic gallstone disease.

\section{Patients and Methods}

This study was conducted in the General Surgery Department at Al-Zahraa University Hospital and Damanhur Medical National Institute. The cases were performed in the period from April 2016 till October 2018. In which 100 patients with symptomatic gallstone disease and with liver cirrhosis including Child class A or Child class B, 
were randomly divided into two groups 50 cases for each. Group (A): Laparoscopic cholecystectomy (LC) and Group (B): Open Cholecystectomy (OC) group.

Inclusion criteria for the studied groups was as the following compensated cirrhotic patients with symptomatic gallstone of Child-pugh A \& early child B All patients were subjected to thorough history and clinical examination focused on manifestation of gallstone disease and chronic liver disease. The following workup were performe:

- Complete blood picture.

- Liver function tests (serum albumin, SGOT, SGPT, prothrombine time, INR).

- Serum creatinine, urine and stool analysis.

- HCV and HBV markers.

- Abdominal ultrasound to show the state of the liver, portal vein, gallbladder, and CBD.

The diagnosis of cirrhosis had been proven on ultrasound finding. The Child-Pugh classification system was used to assess the severity of cirrhosis. No patient in this study had a Child class $\mathrm{C}$ cirrhosis. Informed consent was obtained from every patient for operation and inclusion in the study.

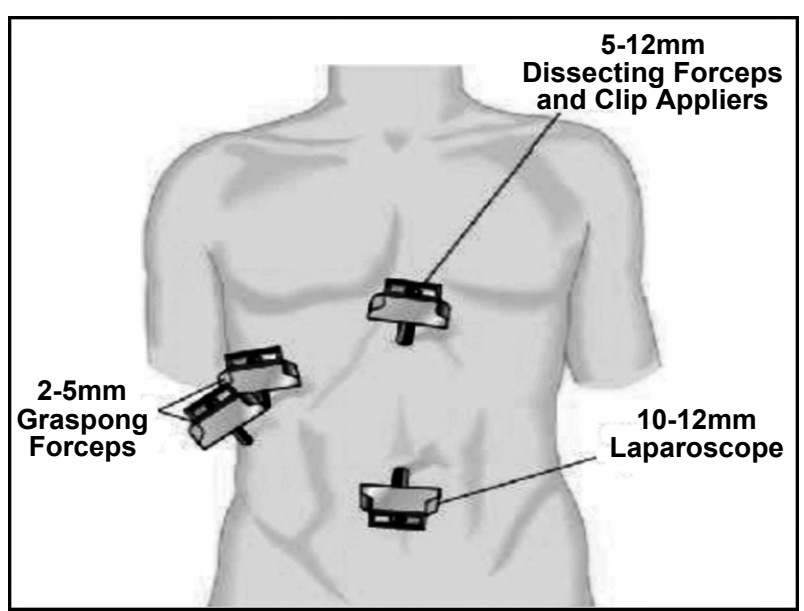

Fig. (1): Positions for ports and laparoscopic instruments placement.

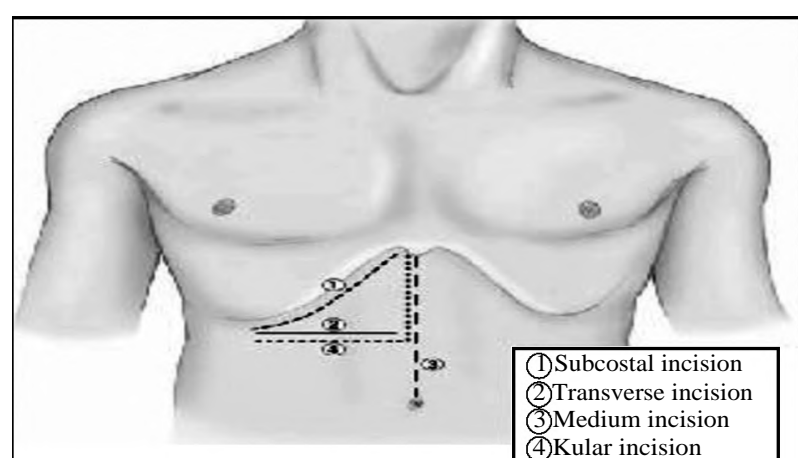

Fig. (2): Types of incisions for open cholecystectomy.
All patients were done under general anesthesia; hepato-toxic drugs were avoided. A standard 4 ports laproscopic procedure was performed for all LC group by using two $5 \mathrm{~mm}$ ports and two $10 \mathrm{~mm}$ ports after pneumoperitoneum was established using a veress needle.

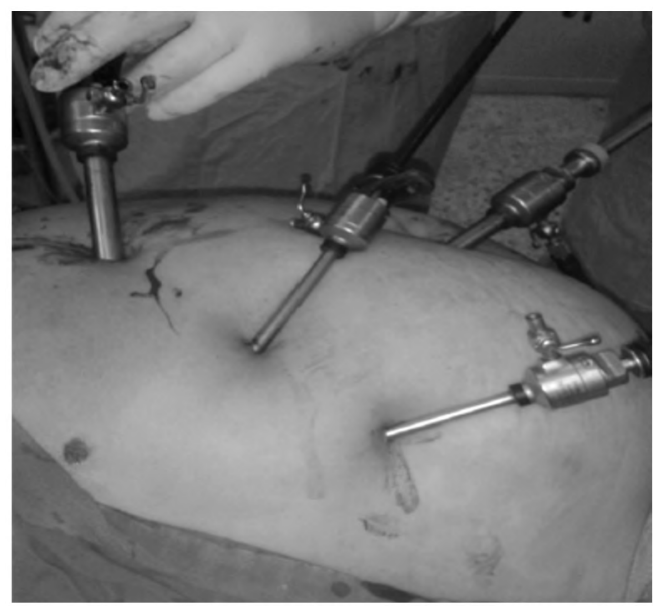

Fig. (3): Positions for ports and laparoscopic instruments placement.

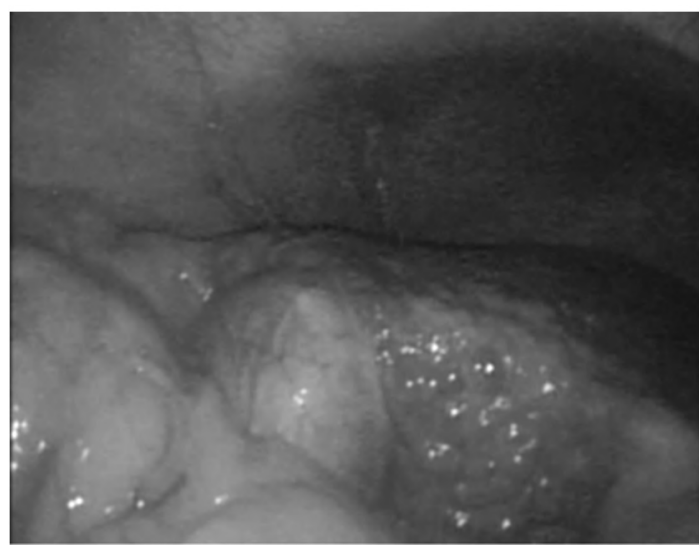

Fig. (4): Nodular cirrohsis.

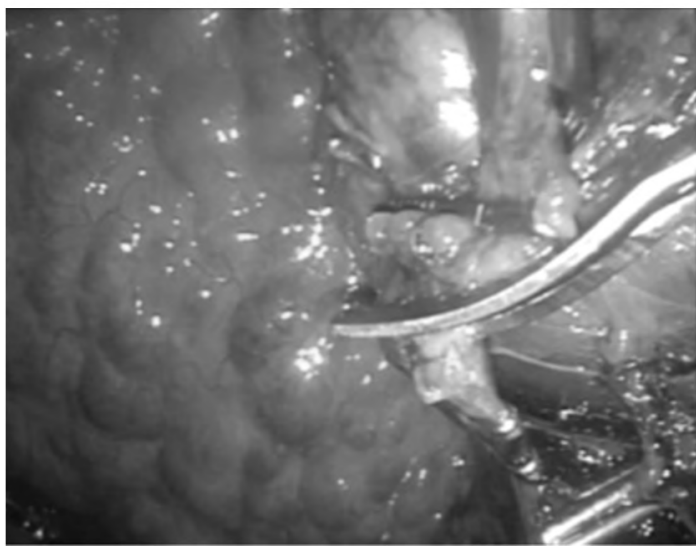

Fig. (5): Cuting of clipped cystic duct. 


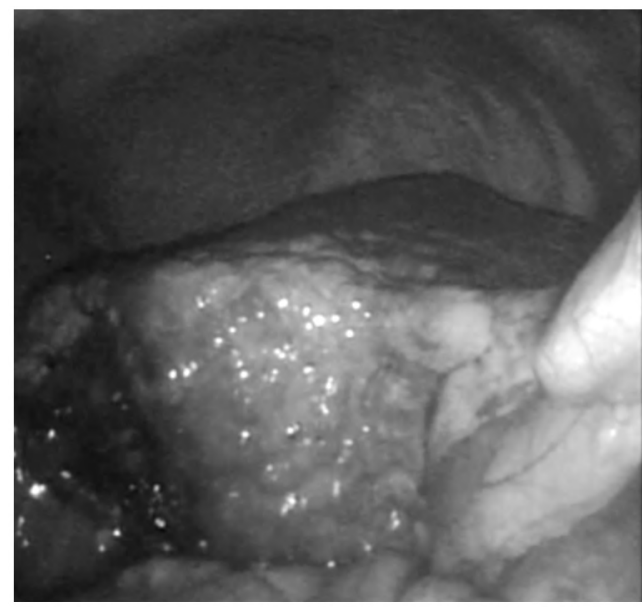

Fig. (6): Final look.

The intra abdominal $\mathrm{CO} 2$ pressure was controlled at the level of $14 \mathrm{mmHg}$. The $\mathrm{OC}$ was performed with a $14 \mathrm{~cm}$ subcostal incision or right upper paramedian incision. Hemostasis was achieved with ligature, electrocautary and ligasure. Abdominal drain was placed in the operative field for all patients.

All data were collected \& statistically analyzed to compare between lap cholecystectomy \& open cholecystectomy in cirrhotic patients, as regard to operative time, intra operative and post-operative blood loss, time to resume diet, complications and mortality incidence, and post-operative subjective pain score.

The patients were followed up weekly for the 1 st month, clinically, laboratory (liver function) and radiological (abdominal ultrasound).

\section{Statistical analyses:}

All data were performed using the SPSS 10.0 software (SPSS Inc., Chicago, IL, USA). The normally distributed variables were compared using Student's $t$-test. The results were expressed as means \pm standard deviation, medians (minimummaximum), or frequencies. Correlation coefficients were calculated to represent the strength between two quantitative variables. Chi-square test was used to determine the relationship between two qualitative variables. And Wilcoxon's rank sum test for variable with continuous or ordinal distributions. $p$-value of $<0.05$ was considered statistical significance.

\section{Results}

The demographic data for both groups were shown in (Table 1) with no applied math distinction determined between the both groups as regard to age, and sex (Table 1).
Table (1): Patient's demographic data

\begin{tabular}{|c|c|c|c|c|c|c|c|}
\hline & \multicolumn{2}{|c|}{$\begin{array}{c}\text { Group A } \\
(\mathrm{n}=50)\end{array}$} & \multicolumn{2}{|c|}{$\begin{array}{c}\text { Group B } \\
(\mathrm{n}=50)\end{array}$} & \multirow{2}{*}{$\begin{array}{c}\text { Test } \\
\text { of sig. }\end{array}$} & \multirow{2}{*}{$p$} \\
\hline & & No. & $\%$ & $\mathrm{~N}$ & $\%$ & & \\
\hline \multicolumn{8}{|l|}{ Sex: } \\
\hline \multicolumn{2}{|c|}{ Male } & 30 & 60.0 & 32 & 64.0 & $\chi^{2}=$ & \multirow[t]{2}{*}{0.680} \\
\hline Fem & & & 40.0 & 18 & 36.0 & 0.170 & \\
\hline \multicolumn{8}{|c|}{ Age (years): } \\
\hline \multirow{3}{*}{\multicolumn{2}{|c|}{$\begin{array}{l}\text { Min.-max. } \\
\text { Mean } \pm \text { SD. } \\
\text { Median }\end{array}$}} & \multirow{2}{*}{\multicolumn{2}{|c|}{$\begin{array}{l}40.0-62.0 \\
48.0 \pm 5.11\end{array}$}} & \multirow{2}{*}{\multicolumn{2}{|c|}{$\begin{array}{l}38.0-61.0 \\
45.66+6.17\end{array}$}} & \multirow{3}{*}{$\begin{array}{l}t= \\
2.065^{*}\end{array}$} & \multirow[t]{3}{*}{$0.042 *$} \\
\hline & & & & & & & \\
\hline & & 46.5 & & & & & \\
\hline \multicolumn{8}{|c|}{ Table (2): Severity of liver cirrhosis. } \\
\hline \multirow[t]{2}{*}{ Child } & \multicolumn{3}{|c|}{$\begin{array}{c}\text { Group A } \\
(\mathrm{n}=50)\end{array}$} & \multicolumn{2}{|c|}{$\begin{array}{c}\text { Group B } \\
(\mathrm{n}=50)\end{array}$} & \multirow[t]{2}{*}{$\chi^{2}$} & \multirow{2}{*}{$p$} \\
\hline & No. & $\%$ & & No. & $\%$ & & \\
\hline A & 40 & 80. & & 42 & 84.0 & 0.271 & 0.603 \\
\hline B & 10 & 20. & & 8 & 16.0 & & \\
\hline
\end{tabular}

Severity of liver cirrhosis is shown in (Table 2). In LC (Group A): 40 patients were child $A$ and 10 patients were child $\mathrm{B}$. While in OC (Group B): 42 patients were child $A$ and 8 patients were child B.

Table (3): Cause of liver cirrhosis.

\begin{tabular}{lllllll}
\hline & \multicolumn{6}{c}{ Group A Group B } \\
Cause of cirrhosis & $(\mathrm{n}=50)$ & $(\mathrm{n}=50)$ & $\chi^{2}$ & $p$ \\
& No. & $\%$ & No. & $\%$ & & \\
\hline Bilharzial & 28 & 56.0 & 27 & 54.0 & 0.633 & 1.000 \\
Positive HBV & 5 & 10.0 & 4 & 8.0 & & \\
Positive HCV & 16 & 32.0 & 17 & 34.0 & & \\
Positive HCV \& HBV & 1 & 2.0 & 2 & 4.0 & & \\
\hline
\end{tabular}

Causes of liver cirrhosis are shown in (Table 3). In LC (Group A): Group cirrhosis was diagnosed as secondary to hepatitis $\mathrm{C}$ in 16 patients, hepatitis $B$ in 5 patients, hepatitis C and B in 1 patient and pure bilharzial periportal fibrosis in 28 patients. While in OC (Group B): Cirrhosis was diagnosed as secondary to hepatitis $\mathrm{C}$ in 17 patients, hepatitis $B$ in 4 patients, hepatitis $C$ and $B$ in 2 patients and 27 had pure bilharzial peiportal fibrosis.

Table (4): Mean surgical times.

\begin{tabular}{|c|c|c|c|c|}
\hline Operative time & $\begin{array}{c}\text { Group A } \\
(\mathrm{n}=48)\end{array}$ & $\begin{array}{c}\text { Group B } \\
(n=52)\end{array}$ & $\mathrm{U}$ & $p$ \\
\hline Min.-Max. & $55.0-97.0$ & $70.0-130.0$ & $104.0 *$ & $<0.001 *$ \\
\hline Mean \pm SD. & $63.58 \pm 9.93$ & $97.69 \pm 15.79$ & & \\
\hline Median & 62.0 & 96.0 & & \\
\hline
\end{tabular}

Mean surgical times were significantly shorter in LC (Group A) group. The mean $\pm \mathrm{SD}$ (in minutes) of OC (Group B) group and LC (Group A) 
group was $97.69 \pm 15.79$ versus $63.58 \pm 9.93$, respectively, $(p<0.001)$ shown in (Table 4$)$.

Table (5): The mean time to resume diet.

\begin{tabular}{lllll}
\hline $\begin{array}{l}\text { Time to } \\
\text { resume diet }\end{array}$ & $\begin{array}{l}\text { Group A } \\
(\mathrm{n}=48)\end{array}$ & $\begin{array}{l}\text { Group B } \\
(\mathrm{n}=52)\end{array}$ & $\mathrm{U}$ & $p$ \\
\hline Min.-Max. & $6.0-30.0$ & $12.0-45.0$ & $190.50^{*}$ & $<0.001^{*}$ \\
Mean \pm SD. & $10.69 \pm 5.41$ & $24.15 \pm 6.74$ & & \\
Median & 8.0 & 20.0 & & \\
\hline
\end{tabular}

The mean time to resume diet (hours) was $10.69 \pm 5.41$ in LC (Group A) group was significantly earlier than in OC (Group B) group 24.15 $\pm 6.74(p<0.001)$ shown in (Table 5).

Table (6): The length of hospital stay (days).

\begin{tabular}{lllll}
\hline Hospital day & $\begin{array}{c}\text { Group A } \\
(\mathrm{n}=48)\end{array}$ & $\begin{array}{l}\text { Group B } \\
(\mathrm{n}=52)\end{array}$ & $t$ & $p$ \\
\hline Min.-Max. & $2.0-4.0$ & $3.0-9.0$ & $10.603^{*}$ & $<0.001^{*}$ \\
Mean \pm SD. & $2.60 \pm 0.61$ & $5.08 \pm 1.56$ & & \\
Median & 3.0 & 6.0 & & \\
\hline
\end{tabular}

The length of hospital stay (days) was significantly longer in OC (Group B) group with a mean hospital stay $5.08 \pm 1.56$, compared with a mean hospital stay $2.60 \pm 0.61$ for LC (Group A) group $(p<0.001)$ as shown in (Table 6$)$.

Table (7): Blood loss.

\begin{tabular}{lllll}
\hline Blood loss & \multicolumn{1}{c}{$\begin{array}{c}\text { Group A } \\
(\mathrm{n}=48)\end{array}$} & \multicolumn{1}{c}{$\begin{array}{c}\text { Group B } \\
(\mathrm{n}=52)\end{array}$} & $\mathrm{U}$ & $p$ \\
\hline Min.-Max. & $100.0-300.0$ & $200.0-1000.0$ & $225.0^{*}$ & $<0.001 *$ \\
Mean \pm SD. & $185.21 \pm 46.95$ & $444.81 \pm 147.44$ & & \\
Median & 180.0 & 410.0 & & \\
\hline
\end{tabular}

The mean blood loss in OC (Group B) group was $444 \pm 147 \mathrm{~mL}$, and a mean of $185.21 \pm 46.95 \mathrm{~mL}$ in LC (Group A) $(p<0.001)$ as shown in (Table 7).

Table (8): Post-operative pain score.

\begin{tabular}{llllc}
\hline $\begin{array}{l}\text { Post-operative } \\
\text { pain score }\end{array}$ & $\begin{array}{c}\text { Group A } \\
(\mathrm{n}=48)\end{array}$ & $\begin{array}{c}\text { Group B } \\
(\mathrm{n}=52)\end{array}$ & $\mathrm{U}$ & $p$ \\
\hline $\begin{array}{l}\text { Day 1: } \\
\text { Min.-Max. }\end{array}$ & $3.0-6.0$ & $4.0-9.0$ & $71.0^{*}$ & $<0.001 *$ \\
Mean \pm SD. & $4.15 \pm 0.65$ & $6.90 \pm 0.96$ & & \\
Median & 4.0 & 7.0 & & \\
Day 7: & & & & \\
Min.-Max. & $1.0-3.0$ & $1.0-5.0$ & $87.0^{*}$ & $<0.001 *$ \\
Mean \pm SD. & $1.38 \pm .61$ & $3.90 \pm .87$ & & \\
Meian & 1.0 & 4.0 & & \\
\hline
\end{tabular}

Also, pain score measured in $1 \mathrm{st}, 2 \mathrm{nd}$ and 7 th day significantly reduced in LC (Group A) group $(p<0.001)$ as shown in (Table 8).
Table (9): Complications

\begin{tabular}{|c|c|c|c|c|c|c|}
\hline \multirow[t]{2}{*}{ Complications } & \multicolumn{4}{|c|}{$\begin{array}{l}\text { Group A Group B } \\
(\mathrm{n}=50) \quad(\mathrm{n}=50)\end{array}$} & \multirow[t]{2}{*}{$x^{2}$} & \multirow[t]{2}{*}{$p$} \\
\hline & No. & $\%$ & No. & $\%$ & & \\
\hline • No & 42 & 84.0 & 20 & 40.0 & $20.543 *$ & $<0.001 *$ \\
\hline - Yes & 8 & 16.0 & 30 & 60.0 & & \\
\hline - Wound infection & 1 & 2.0 & 10 & 20.0 & & \\
\hline •Ascitic leak & 2 & 4.0 & 4 & 8.0 & & \\
\hline - Chest infection & 2 & 4.0 & 4 & 8.0 & & \\
\hline • Conversion to open & 2 & 4.0 & 0 & 0.0 & & \\
\hline $\begin{array}{l}\text { - Deterioration of liver } \\
\text { function }\end{array}$ & 1 & 2.0 & 6 & 12.0 & & \\
\hline • Incisional hernia & 0 & 0.0 & 2 & 4.0 & & \\
\hline - Mild encephalopathy & 0 & 0.0 & 2 & 4.0 & & \\
\hline $\begin{array}{l}\text { - Need blood } \\
\text { transfusion } \\
\text { - Intraoperative no }\end{array}$ & 0 & 0.0 & 2 & 4.0 & & \\
\hline
\end{tabular}

Post-operative complications for each group were presented in (Table 9). In LC (Group A) group, 8 post-operative complications occurred in 8 patients. While in OC (Group B) group, 30 postoperative complications occurred in 30 patients. Patients' morbidity was more frequent in OC (Group B) group than LC (Group A) group, statistically significant difference observed in wound complication $(p<0.001)$ and deterioration of liver function $(p<0.001)$. No operative mortality in both groups.

\section{Discussion}

Cholelithiases in patients with cirrhosis occurs twice as often as in general population [6]. That is caused by increased intravascular hemolysis, hypersplenism and increased level of estrogen with reduction in gallbladder emptying and motility [7]

Gallstone disease is a major problem world wide particularly in adult population. Its incidence shows a considerable geographical and regional variation [8], the morbidity and mortality associated with cholecystectomy has decreased to an extremely low level in past few decades [8]

Since the introduction of LC, the question of whether cirrhotic patients might benefit from this less invasive approach has arisen. It is well known that LC allows for shorter hospital stays, operative times, faster operative rehabilitation, reduced wound complications and less total costs for noncirrhotic patients when compared with open cholecystectomy [9].

In this study the age ranged from (38 to 62) years in both groups with mean age of $(45.66 \pm 6.17)$ years for OC group and $(48 \pm 5.11)$ year for LC 
group. The peak age group for presentation of gallstones in our study was (38 to 52) years which differ from other study where the peak age group was (33 to 44) year [10], (13 to 90) year with a mean age of (48.4 year, 59 year for OC and 49 years for LC group Rosen Muller, 2007 [15], 60 years for OC and 54 years for LC group Meyer, 1993 [14].

The operative time in our study was significantly shorter in LC group (63.58 \pm 9.93$)$ minutes than OC group (97.69 \pm 15.79$)$ minutes. The mean operative time given by Khan \& Oonwala 2007 [12] was $(60.5 \pm 17.5)$ for $\mathrm{OC}$ and $(62 \pm 15.2)$ minutes for LC group. This is opposite to our study which shows shorter operative time in LC group patients.

The time factor in our study is very important as cirrhotic patients at LC group are exposed less to anesthesia than OC group so less deterioration of the exhausted liver. We should remember that all cirrhotic patients at this study were exposed to isoflurane which is more safe than halothan and thus better for cirrhotic patients.

The morbidity of OC in cirrhotics was due to massive intraoperative bleeding and wound problems [13].

In this study the open group had 30 complications $(60 \%)$, one of which was severe bleeding that required blood transfusion. And the laparoscopic group had 8 complications $(16 \%)$. This study found that the laparoscopic approach had significantly less complications than the open one, especially regarding bleeding and wound infection, and this agree with Poggio et al., 2000 [16] who have found that the laparoscopic approach had significantly less complications than the open one, especially regarding bleeding and wound infection, and differ from Hamade et al., 2010 [17] who had found that complication is the same in both groups.

The hospital stay in this study was $(2.60 \pm 0.61$ day) in LC group and (5.08 \pm 1.56 day) in OC group It is comparable to other studies given by different authors like 5.1 days in OC vs. 2.5 days in LC Gabriel, 2009 [18], 7.9 days in OC vs. 2.6 days in LC Rosen muuller, 2007 [15] , $6.5 \pm 3$ days for OC and $2 \pm 2$ days for LC. In this study, operative times, hospital stay and post-operative pain were shorter in the LC group than the OC group and also, the low occurrence of post-operative ileus and early resumption to diet in LC group because there's no intraoperative intestinal retraction and less pain explain this state also confirmed by Wu et al., 2004 [14].
In this study post-operative pain in the LC was less than the OC as we found patients exposed to LC need (1-2) analgesic ampoule to (2-4) ampoule in OC.

Care must be taken at the beginning of LC, to avoid injury of dilated abdominal wall veins. The $10 \mathrm{~mm}$ subxiphoid port was placed more to the right of the midline to avoid the falciform ligament and accompanying umbilical vein.

In this study the reduced blood loss in LC group, whether operative or postoperative, is related to meticulous dissection (magnified surgical field) and pneumoperitonum barohemostatic effect and using Ligasure in dissection these data correlate with finding of Wu et al., 2004 [14] \& Poggio et al., 2000 [16]

Wound complications as infections, dehiscence, and post-operative hernia increased the postoperative morbidity for OC group. Bloch et al., 2000 [13] reported an incidence of $12 \%$. One wound complications in our LC group in contrast to12 wound complication in OC group. Reduction of wound related complication in laparoscopic cholecystectomy LC made more favorable post-operative outcome in cirrhotics.

Also, in laparoscopic cholecystectomy group there was no parietal incision that decrease the incidence of chest complications as reported by Poggio et al., 2000 [16]. Also, the reduced bleeding, minimal dissection, short operative and anesthetic time, all explain the lack of deterioration of liver function in LC group than OC group. This finding was also reported by Poggio et al., 2000; Schiff et al., 2005 [16,20].

In this study we found less blood loss, shorter operative time and shorter length of hospitalization in LC. This agreed with Puggioni \& Wong 2003 [21] who conducted a meta-analysis that included studies of cirrhotic patients submitted to laparoscopic cholecystectomy. They concluded that the laproscopic approach for cholecystectomy offers advantages of less blood loss, shorter operative time and shorter length of hospitalization.

There are other potential benefits of LC for cirrhotic patients, which have been well described, including the cosmetic effect and reduction in abdominal adhesion, the former may be of value in females. The latter may be beneficial for cirrhotic patients requiring liver transplantation (Hamad et al., 2010) [17]. 
Puggioni \& Wong 2003 [21] conducted a similar meta-analysis, but his review included only four studies with 90 cirrhotic patients. Their conclusions agreed with our study in terms of mortality, hospital stay and blood loss, but differed from our study in terms of morbidity, operative time and wound infection.

Safety is a major concern for cirrhotic patients. There is no mortality in either groups and significantly lower morbidity in the LC group than OC group. It seems LC is safer than OC, or at least not worse than OC. We attribute it to the development of surgical instruments (e.g. harmonic scalpel, high-definition camera), the growing experience of surgeons and the selection of patients most of them were in Child-Pugh class A or class B).

Conversion to $\mathrm{OC}$ was necessary in two patients throughout LC due to uncontrollable liver bed hemorrhage in one patient and lean visualization of the anatomy within the another patient.

A low threshold for conversion from LC to OC should be maintained. Conversion is not a complication, but a means to prevent more serious problems. Absolute indications to convert include bleeding not readily controlled laparoscopically and an inability to recognize the anatomy properly. The surgeon should not be reluctant to convert immediately to $\mathrm{OC}$ when there is uncertainty about the safety and efficiency of the operative procedure.

None of the patients in the LC group required any blood component replacement during their hospital stay. In contrast, 2 patients in the OC group required blood transfusions during surgery ranging from 1 unit of packed red blood cells in one patient and 3 units of whole blood in the other patients.

Schwartz 1994 reported that $57 \%$ of 21 patients with cirrhosis undergoing $\mathrm{OC}$ required a transfusion of 3 or more units of blood. In our study, 4 patients in the OC group needed transfusion, in contrast to none of the patients in the LC Group.

\section{Conclusion:}

Laparoscopic Cholecystectomy (LC) offered safe and effective surgical treatment for cirrhotic patients of (Child class A and early B) suffering from gallstone disease. The results of our study confirmed that LC is a safe operative approach in most patients with Child class A and B and symptomatic gallstone disease.

\section{LC offers the following advantages:}

- Shorter anesthetic and surgical times.

- Reduced hospital stay.

- Reduce blood loss.

- Fewer operative and post-operative complications.

The procedure is still complicated and highly difficult which associates with significant morbidity compared with that of patients without cirrhosis. To achieve these advantages in patients with cirrhosis, only experienced laparoscopic surgeon should perform this procedure.

\section{References}

1- ACALOVSCHI M., DUMITRASCU and NICOARA: Gallstones in patients with liver cirrhosis: Incidence, etiology, clinical and therapeutical aspects. World J. Gastroenterol., 20 (23): 7277-85, 2014.

2- CONTE D., BARISANI D., MANDELLI P., BODINI P., BORZOI M. and PISTOSO S.: Cholethiases in cirrhosis. Analysis of 500 cases. Am. J. Gastroenterology, 86: 162932, 1991.

3- NUSRAT S., KHAN M.S., FAZILI J. and MADHOUN M.F.: Cirrhosis and its complications: Evidence based treatment. World J. Gastroenterol., 20: 5442-60, 2014.

4- CURET M.J., CONTER M., WEBER D.M. and ABRECHT R.: Laproscopic cholecystectomy. Surg. Endosc., 16: 453-7, 2002.

5- DURAND F. and VALLA D.: Assessment of the prognosis of cirrhosis: Child-Pugh versus MELD/Journal of Hepatology, 42: S 100-S107, 2005.

6- TUECH J.J., PESSAUX P. and REGENET N.: Laproscopic cholecystectomy in cirrhotic patients. Surg. Laprosc. End., 4: 227-31, 2002.

7- W.H. SCHWESINGER, W.E. KURTIN, B.A. LEVINE and C.P. PAGE: Levine: Cirrhosis and alcoholism as pathogenic factors in pigmented gallstones formation. Ann. Surg., 201: 319-22, 2005.

8- MIRZA M.A., WASTY W.H. HABIB L., JALEEL F., SAIRA M.S. and SARWAR M.: An audit of cholecystectomy. Pakist. J. Sur., 23: 104, 2007.

9- JI WU, LI L.T., WANG Z.M., et al.: A randomized controlled trial of laparoscopic versus open cholecystectomy in Am. J. Surg., 165: 459-65, 2005.

10- CHANNA N.A., SOOMRO A.M. and GHANGRO A.B.: Cholecystectomy is becoming an increasingly common operation in Hyderabad and adjoining areas. Rawal Med. J., 32 (2): 128-30, 2007.

11- MURSHID K.R.: Symptomatic gallstones: A disease of young Saudi women. Saudi J. Gastroenterol., 4: 159-62, 1998.

12- KHAN S. and OONWALA Z.G.: An audit of laparoscopic cholecystectomy. Pak. J. Surg., 23: 100-3, 2007.

13- BLOCH R.S., ALLABEN R.D. and WALT A.J.: Cholecystectomy in cirrhotic patients with cirrhosis. A surgical challenge. Arch. Surg., 120: 669-72, 2000. 
14- MEYER C., De MAMZINI N., ROHR S., THIRY C.L., PERIMKHALIL F.C. and BACHELLIER BILLOT C.: 1000 cases of cholecystectomy 500 by laparotomy versus 500 by laparoscopy. J. Chir. (Paris), 130: 501-6, 1993.

15- ROSEN MUULLER M., HAAPAMAKI M.M., NORDIN P., STENLUND H. and NILSSON E.: Cholecystectomy in Sweden 2000-2003: A nationwide study on procedures patient characteristic and mortality. BMC Gastroenterol., 7 (1): 35, 2007.

16- POGGIO J.L., ROWLAND C.M., GORES G.J., NAGORNEY D.M. and DONOHUE J.H.: A comparison of laparoscopic and open cholecystectomy in patients with compensated cirrhosis and symptomatic gallstone disease. Surgery, 127: 405-11, 2000.

17- HAMAD M.A., THABET M., BADAWY A., MOURAD F., ABDEL-SALAM M. and ABDEL-RAHMAN: Laparoscopic versus open cholecystectomy in patients with liver cirrhosis: A prospective, randomized study. J. Laparoendosc. Adv. Surg. Tech., 20 (5): 405-9, 2010.

18-GABRIEL R., KUMAR S. and SHRESTHA A.: Evaluation of predictive factors for conversion of laparoscopic cholecystectomy. Kathmandu Uni. Med. J., 7: 26-30, 2009.

19- WU JI, LING-TANG LI, XUN-RU CHEN, JIE-SHOU LI and NANJING, CHINA: Application of laparoscopic cholecystectomy in patients with cirrhotic portal hypertension. Hepatobilary Pancreat. Dis. Int., 3: 270-4, 2004.

20- SCHIFF J., MISRA M., RENDON G., ROTHSCHILD J. and SCHWAITZBERG S.: Laparoscopic cholecystectomy in Cirhotic patients. Surg. Endosc., 19: 1278-81, 2005.

21- PUGGIONI A. and WONG L.L.: A metaanalysis of laparoscopic cholecystectomy in patients with cirrhosis. JACS, 197: 921-6, 2003.

22- SCHWARTZ S.I.: Principles of Surgery. New York: McGraw-Hill, 1369, 1994.

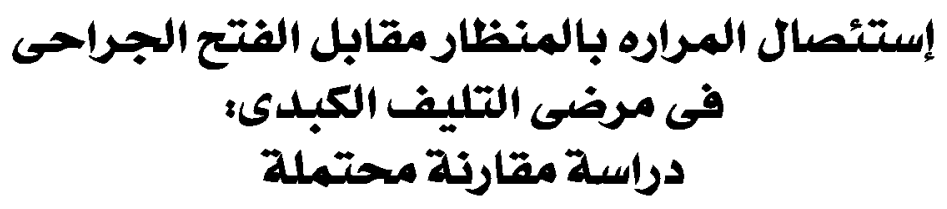

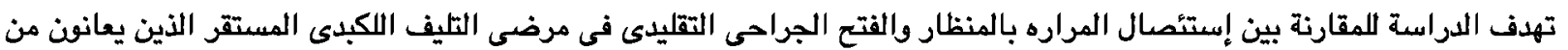

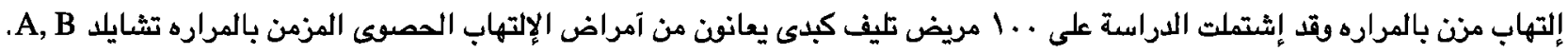

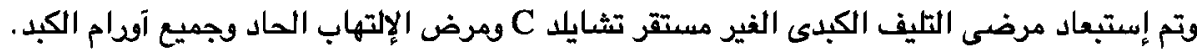

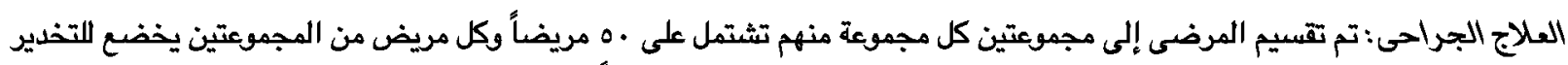

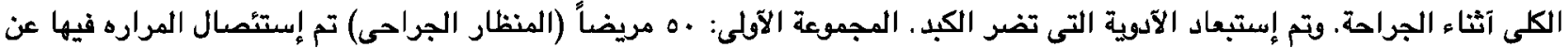

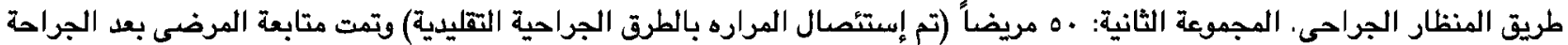
وتدوين الآتى:

زمن الجراحة وكمية الدم المفقوده آثناء وبعد الجراحة ودرجة الإحساس بالآلم وحدوث مضاعفات بعد الجراحة مثل (الإستقساء، الغيبوية

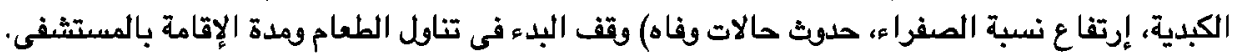

$$
\text { وقذّ خلص البحث للآتى: }
$$$$
\text { ا- (- وقت العملية آقل. }
$$$$
\text { Y- كمية نزيف آقل. }
$$$$
\text { ب- بإمامة بالمستشفى آقل. }
$$$$
\text { ع- بلءء تناول الطعام والشراب آسرع. }
$$

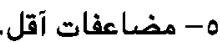$$
\text { 7- وقد آثبت ذلك البحث بالآرقام والنسب. }
$$ 